\title{
FEATURE Carbon losses in terrestrial hydrological pathways in sugarcane cropping systems of Australia
}

\author{
Gunasekhar Nachimuthu, Michael J. Bell, and Neil V. Halpin
}

C limate change and carbon (C) sequestration are a major focus of research in the twenty-first century. Globally, soils store about 300 times the amount of $\mathrm{C}$ that is released per annum through the burning of fossil fuels (Schulze and Freibauer 2005). Land clearing and introduction of agricultural systems have led to rapid declines in soil C reserves. The recent introduction of conservation agricultural practices has not led to a reversing of the decline in soil $\mathrm{C}$ content, although it has minimized the rate of decline (Baker et al. 2007; Hulugalle and Scott 2008). Lal (2003) estimated the quantum of $\mathrm{C}$ pools in the atmosphere, terrestrial ecosystems, and oceans and reported a "missing C" component in the world $\mathrm{C}$ budget. Though not proven yet, this could be linked to C losses through runoff and soil erosion (Lal 2005) and a lack of $\mathrm{C}$ accounting in inland water bodies (Cole et al. 2007). Land management practices to minimize the microbial respiration and soil organic $\mathrm{C}$ (SOC) decline such as minimum tillage or no tillage were extensively studied in the past, and the soil erosion and runoff studies monitoring those management systems focused on other nutrients such as nitrogen $(\mathrm{N})$ and phosphorus $(\mathrm{P})$. There is limited literature reporting the soil erosion and spatial distribution of SOC pools at different stages of erosion, and there is also a lack of information on the terrestrial losses of SOC through hydrological pathways and soil erosion (Chappell et al. 2015) in different farming systems. In this article, we discuss soil C losses in runoff and erosion from

Gunasekhar Nachimuthu is a soil scientist in the New South Wales Department of Primary Industries, Australian Cotton Research Institute, Narrabri, New South Wales, Australia. Michael J. Bell is professor of tropical agronomy in the School of Agriculture and Food Sciences, University of Queensland, Gatton Queensland, Australia. Neil V. Halpin is a senior agronomist (coastal farming systems) in the Queensland Department of Agriculture and Fisheries, Bundaberg Research Facility, Kalkie, Queensland, Australia. sugarcane farming systems in subtropical northeast Australia.

\section{SUGARCANE PRODUCTION IN AUSTRALIA AND SMARTCANE BMP}

In Australia, sugarcane production is concentrated in two eastern states (coastal Queensland and northeast New South Wales), with the sugarcane producing regions extending from Mossman in far north Queensland to Grafton in northern New South Wales (figure 1). The Australian sugar industry produced 32.36 million $\mathrm{t}$ ( 35.67 million $\mathrm{tn})$ of cane from 377,800 ha $(933,564 \mathrm{ac})$ with an average productivity of $85.74 \mathrm{t} \mathrm{ha}^{-1}(38.24$ tn $\mathrm{ac}^{-1}$ ) (ASMC 2016) in the 2014 season, with production statistics for each state from 2005 to 2014 detailed in table 1. Australian sugarcane growers are committed to sustainable production practices, with around $75 \%$ of growers from the environmentally sensitive regions of Mackay/Whitsunday, Burdekin, and the Wet Tropics voluntarily showing interest to participate in the industry's best management program named Smartcane BMP (Smartcane BMP 2015). This program was initiated in 2013 in response to government and community concerns relating to potential off-farm environmental risks to the Great Barrier Reef (GBR) from high fertilizer and herbicide use by the sugarcane industry in catchments discharging into the GBR lagoon (Nachimuthu et al. 2016). The focus was on the adoption of improved management practices to reduce off-farm environmental impacts from sugarcane production.

The Smartcane BMP program contains seven modules for growers, which include the following:

1. Drainage and irrigation management (core)

2. Pest, disease, and weed management (core)

3 . Soil health and plant nutrition management (core)

4. Crop production and harvest management

5. Natural systems management

6. Workplace health and safety management

7. Farm business management
Although soil health and plant nutrition management are listed as core modules of Smartcane BMP, there is a lack of information on $\mathrm{C}$ flow in sugarcane cropping systems. To address this gap, we report data quantifying the annual runoff losses of C from contrasting sugarcane cropping systems in southeastern Queensland and integrate that information with other published data on C losses via terrestrial hydrological pathways. This analysis will provide information that could assist the sugar industry to improve its Smartcane BMP program and the overall sustainability of sugarcane production systems.

\section{CARBON LOSSES IN RUNOFF FROM}

SUGARCANE FARMING SYSTEMS IN SOUTHEAST QUEENSLAND, AUSTRALIA Under the Paddock to Reef program (Carroll et al. 2012), a trial to assess the impact of a range of land management practices on productivity and off-farm water quality was conducted in the Burnett-Mary catchment, which discharges into the southern GBR lagoon. A sugarcane plant crop was managed using four different sets of practices. These are described as (1) Conventional practice-current conventional practice, consisting of full tillage after an intensive vegetable rotation with traditional residual herbicides; (2) Improved practice-where only the beds were tilled after the vegetable phase (zonally tilled with the interspace left undisturbed) and residual herbicide use was reduced; (3) Aspirational practice- a minimum tillage system (one pass of a single tine ripper in the bed zone prior to the vegetable and sugarcane phases), where vegetative trash mulch was maintained during cane planting, no residual herbicides were used, and a legume intercrop was established after cane establishment; and (4) New Farming System-a minimum tillage system (as in Aspirational practice) with grain legume rotation crops, retention of a surface trash mulch, and a combination of residual and knockdown herbicides. 


\section{Figure 1}

Australian sugarcane growing regions (ASMC 2016).

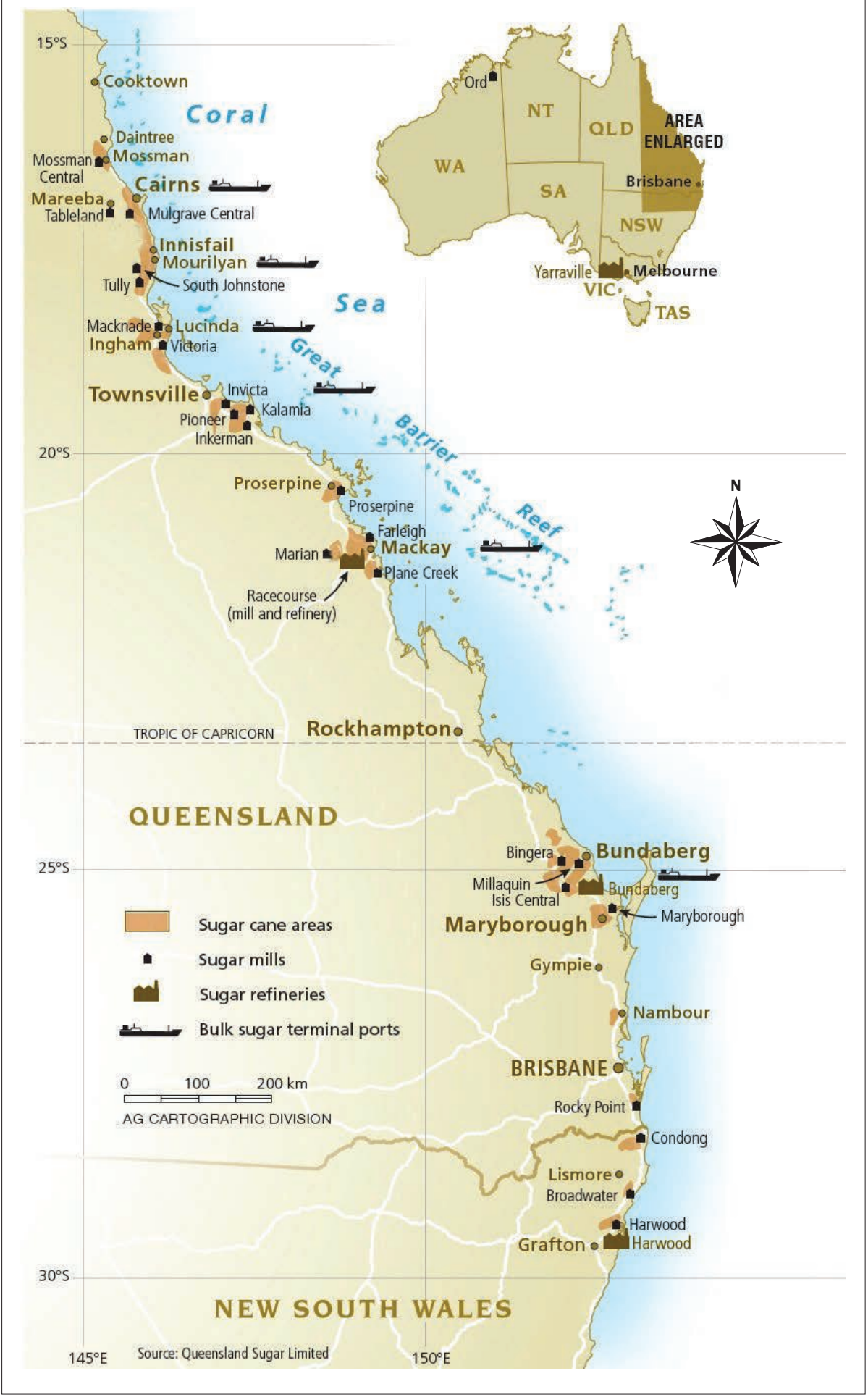

The detailed methodology and experimental site details are described in Nachimuthu et al. (2016). Losses of total organic $\mathrm{C}$ (TOC) and constituent fractions (dissolved organic C [DOC] and particulate organic $\mathrm{C}[\mathrm{POC}]$ ) were quantified in indications that soil and land management practices can influence $\mathrm{C}$ losses through combined effects of runoff volumes and elevated organic $\mathrm{C}$ in topsoils. These measured runoff losses of TOC represent a minor component of total SOC stocks in a soil profile under conventional burnt and green cane trash blanketed (figure 3) systems (e.g., 18 to $20 \mathrm{Mg} \mathrm{C} \mathrm{ha}^{-1}[16,074$ to $\left.17,860 \mathrm{lb} \mathrm{C} \mathrm{ac}^{-1}\right]$ in the 0 to $30 \mathrm{~cm}[12$ in] layer in Bundaberg [Page et al. 2013a]). However, assuming a realistic target for net soil C sequestration of $0.1 \mathrm{t} \mathrm{ha}^{-1} \mathrm{y}^{-1}(0.04$ tn $\mathrm{ac}^{-1} \mathrm{yr}^{-1}$ ) in the top $10 \mathrm{~cm}$ (4 in) of the soil profile, such losses correspond to $12 \%$ to $44 \%$ reduction of those target sequestration rates. This suggests that TOC losses in runoff can have a considerable impact on the net $\mathrm{C}$ balance in topsoils of sugarcane cropping systems. These losses are likely to be accentuated later in the sugarcane crop cycle, especially in trash blanketed systems, given the increased compaction (figure 3)/ reduced infiltration capacity and increased total and labile $\mathrm{C}$ concentration in topsoil layers recorded in late ratoon crops (Bell et al. 2001). Future long-term studies monitoring the SOC sequestration or losses in sugarcane farming systems need to consider runoff and soil erosion losses as a contributory factor in the overall soil $\mathrm{C}$ balance in the topsoil.

\section{EFFECT OF LAND MANAGEMENT PRACTICES ON RUNOFF CARBON LOSSES IN SUGARCANE CROPPING SYSTEMS}

Soil management practices had significant influence on DOC and TOC losses. The Conventional practices resulted in the highest off-site runoff losses of TOC and DOC, followed by the New Farming System (table 2 and figure 2), while the lowest losses occurred from the Improved practices. Treatments that employed minimum tillage produced less offsite DOC losses than conventionally tilled systems, with results consistent with previous studies suggesting an increase in tillage intensity leads to higher DOC losses in runoff (Locke et al. 2015). The lower C losses under minimum tillage are consistent with observations of greater microaggregate formation and subsequent $\mathrm{C}$ stabilization inside microaggregates under minimum tillage practices (Six et al. 2000, 2004). 
Table 1

Australian sugarcane production statistics.

\begin{tabular}{|c|c|c|c|c|c|c|c|c|c|c|}
\hline Statistic & 2005 & 2006 & 2007 & 2008 & 2009 & 2010 & 2011 & 2012 & 2013 & 2014 \\
\hline \multicolumn{11}{|c|}{ Area harvested for milling (ha) } \\
\hline Queensland & 381,029 & 378,966 & 370,669 & 353,428 & 344,102 & 288,716 & 352,646 & 348,594 & 356,206 & 363,339 \\
\hline New South Wales & 17,827 & 17,542 & 17,155 & 14,723 & 15,561 & 14,162 & 13,240 & 11,450 & 14,860 & 14,461 \\
\hline Australia & 398,856 & 396,508 & 387,824 & 368,151 & 359,663 & 302,878 & 365,886 & 360,044 & 371,066 & 377,800 \\
\hline \multicolumn{11}{|l|}{ Cane crushed $(\mathrm{t})$} \\
\hline Queensland & $3.6 \times 10^{7}$ & $3.3 \times 10^{7}$ & $3.2 \times 10^{7}$ & $3.0 \times 10^{7}$ & $2.8 \times 10^{7}$ & $2.6 \times 10^{7}$ & $2.6 \times 10^{7}$ & $2.9 \times 10^{7}$ & $2.9 \times 10^{7}$ & $3.1 \times 10^{7}$ \\
\hline New South Wales & $2.4 \times 10^{6}$ & $2.6 \times 10^{6}$ & $2.2 \times 10^{6}$ & $1.9 \times 10^{6}$ & $1.7 \times 10^{6}$ & $1.7 \times 10^{6}$ & $1.6 \times 10^{6}$ & $9.2 \times 10^{5}$ & $1.3 \times 10^{6}$ & $1.5 \times 10^{6}$ \\
\hline Australia & $3.8 \times 10^{7}$ & $3.6 \times 10^{7}$ & $3.4 \times 10^{7}$ & $3.2 \times 10^{7}$ & $3.0 \times 10^{7}$ & $2.7 \times 10^{7}$ & $2.8 \times 10^{7}$ & $3.0 \times 10^{7}$ & $3.1 \times 10^{7}$ & $3.2 \times 10^{7}$ \\
\hline \multicolumn{11}{|c|}{ Sugar produced (IPS; t) } \\
\hline Queensland & $4.9 \times 10^{6}$ & $4.5 \times 10^{6}$ & $4.5 \times 10^{6}$ & $4.3 \times 10^{6}$ & $4.3 \times 10^{6}$ & $3.2 \times 10^{6}$ & $3.5 \times 10^{6}$ & $4.1 \times 10^{6}$ & $4.2 \times 10^{6}$ & $4.4 \times 10^{6}$ \\
\hline New South Wales & $2.6 \times 10^{5}$ & $2.9 \times 10^{5}$ & $2.3 \times 10^{5}$ & $1.9 \times 10^{5}$ & $1.9 \times 10^{5}$ & $1.8 \times 10^{5}$ & $1.8 \times 10^{5}$ & $1.1 \times 10^{5}$ & $1.6 \times 10^{5}$ & $1.8 \times 10^{5}$ \\
\hline Australia & $5.2 \times 10^{6}$ & $4.8 \times 10^{6}$ & $4.6 \times 10^{6}$ & $4.5 \times 10^{6}$ & $4.5 \times 10^{6}$ & $3.4 \times 10^{6}$ & $3.7 \times 10^{6}$ & $4.2 \times 10^{6}$ & $4.4 \times 10^{6}$ & $4.5 \times 10^{6}$ \\
\hline \multicolumn{11}{|l|}{ Cane harvested (t ha-1) } \\
\hline Queensland & 94.21 & 87.41 & 86.19 & 85.37 & 81.84 & 88.43 & 74.66 & 83.44 & 82.03 & 84.83 \\
\hline New South Wales & 134.29 & 150.68 & 129.73 & 131.22 & 106.28 & 117.65 & 121.86 & 79.92 & 87.61 & 106.75 \\
\hline Australia & 96.00 & 90.21 & 88.12 & 87.20 & 82.90 & 90.61 & 76.37 & 83.33 & 82.25 & 85.74 \\
\hline \multicolumn{11}{|c|}{ CCS/Sugar content (\%) } \\
\hline Queensland & 13.48 & 13.44 & 13.76 & 13.99 & 14.72 & 12.87 & 13.39 & 14.05 & 14.18 & 14.04 \\
\hline New South Wales & 11.16 & 11.13 & 11.85 & 11.61 & 12.94 & 12.10 & 12.17 & 12.02 & 11.92 & 11.36 \\
\hline Australia & 13.33 & 13.27 & 13.64 & 13.85 & 14.62 & 12.82 & 13.32 & 13.99 & 14.08 & 13.91 \\
\hline
\end{tabular}

Long-term SOC monitoring studies in the grains industry in Queensland (Page et al. 2013b) suggested the rate of decline of SOC is lower under no tillage compared to conventional tillage systems, and while this trend was not evident in the much shorter duration tillage trials in the sugar industry (Page et al. 2013a), the runoff C losses were consistent with such a trend. A previous study in conventional sugarcane farming systems in northern Australia reported extremely high values $(260 \mathrm{mg}$ $\left.\mathrm{L}^{-1}\right)$ of DOC concentrations in irrigation runoff (Bohl et al. 2002), which was at least an order of magnitude greater than the DOC event mean concentrations (table 2) recorded in our study (Nachimuthu et al. 2016). However at least 50\% these losses were attributable to cane juice/sugars lost during harvesting and mobilized during irrigation events shortly thereafter. While such losses can produce significant environmental impacts through biologically induced oxygen $\left(\mathrm{O}_{2}\right)$ depletion and fish kills in waterways in cane producing areas, they are not specifically linked to particular soil and land management systems.

\section{Figure 2}

Annual carbon $(C)$ losses in runoff in different sugarcane farming systems in Australia during 2011 to 2012 (TOC = total organic C. POC = particulate organic C. DOC = dissolved organic C).

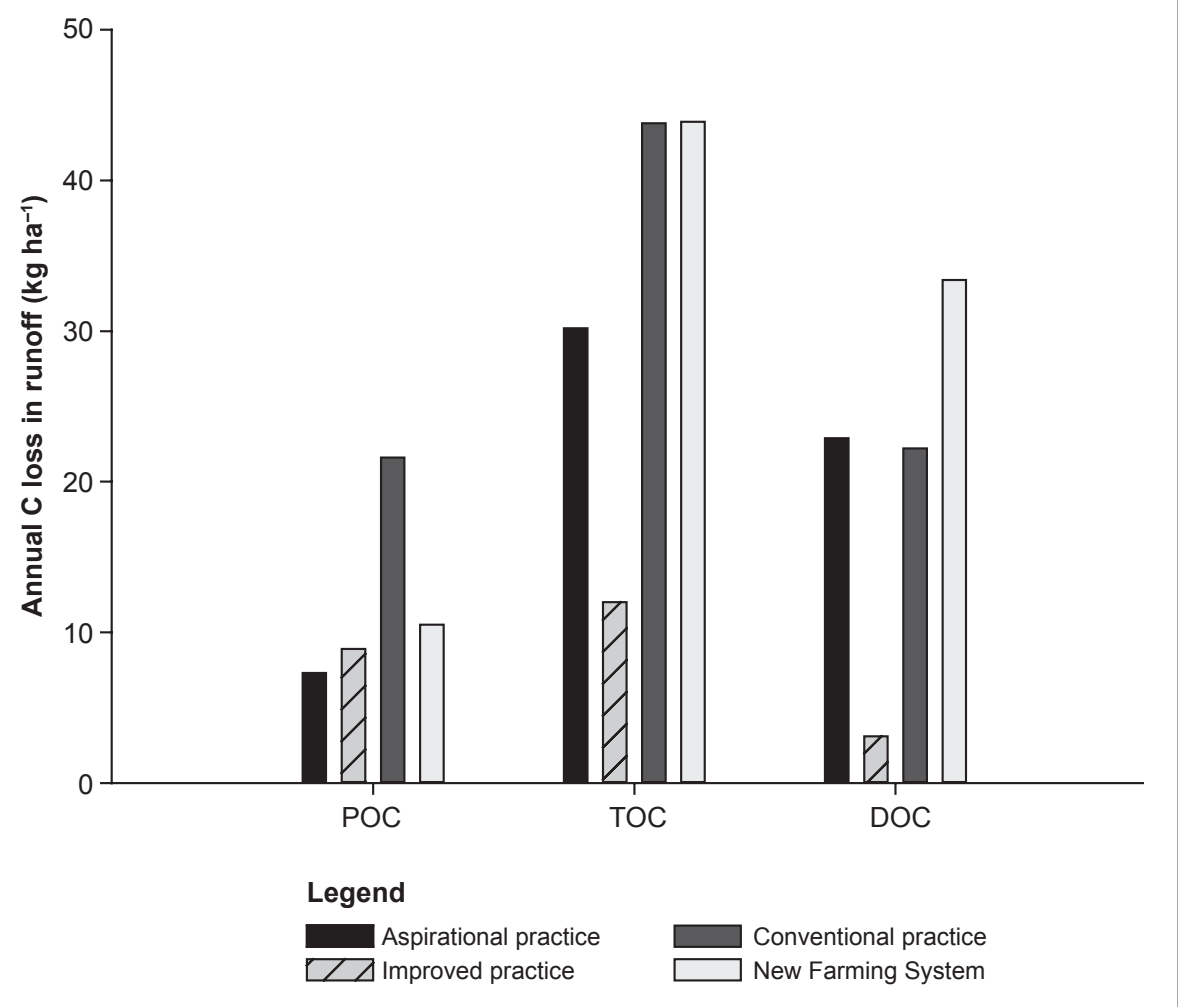




\section{Table 2}

Average concentrations ( $\mathrm{mg} \mathrm{L}^{-1}$ ) of total organic carbon (C) and dissolved organic $\mathrm{C}$ in runoff under different management practices.

\begin{tabular}{lll}
\hline Management practice & $\begin{array}{l}\text { Total organic carbon } \\
\left(\mathbf{m g ~ L} \mathbf{-}^{-1} \text { mean } \mathbf{\pm} \text { SE) }\right.\end{array}$ & $\begin{array}{l}\text { Dissolved organic carbon } \\
\left(\mathbf{m g ~ L}^{-1} ; \text { mean } \pm \text { SE) }\right.\end{array}$ \\
\hline Conventional practice & $33 \pm 8.9$ & $16 \pm 6.5$ \\
Improved practice & $15.3 \pm 8.8$ & $3.8 \pm 1.3$ \\
Aspirational practice & $16.3 \pm 4.3$ & $12.4 \pm 3.5$ \\
New farming systems & $19.6 \pm 5.2$ & $15.2 \pm 4.1$
\end{tabular}

\section{IS THERE EVIDENCE OF DEEP DRAINAGE LOSSES OF DISSOLVED ORGANIC CARBON IN SUGARCANE CATCHMENTS OF AUSTRALIA?}

Farm-level deep drainage studies in sugarcane farming systems of Australia have predominantly focused on $\mathrm{N}$ leaching (Armour et al. 2013; Stewart et al. 2006), with few studies quantifying $C$ losses in deep drainage. However, a limited number of Queensland studies have monitored groundwater DOC concentration in Australian sugarcane landscapes. Early studies reported low DOC concentrations in groundwater in the Pioneer $(<0.5$ to $23 \mathrm{mg}$ DOC L ${ }^{-1}$ ) (Baskaran 2002) and the Don

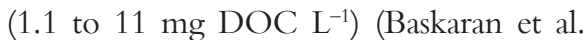
2001) river catchments. In contrast, DOC levels were reportedly much higher in the lower Burdekin region (Thayalakumaran et al. 2008). In this study, most of the $\sim 30$ bore wells surveyed were in sugarcane cropping areas in the coastal zone, with groundwater concentrations of DOC ranging from 4 to $82 \mathrm{mg} \mathrm{L}^{-1}$. Thayalakumaran et al. (2008, 2015) related the high DOC levels in the lower Burdekin region to deep drainage by using a range of measures, which included sampling at different depths and assessing seasonal variation in DOC concentration under different management practices. The authors suggested that high DOC concentrations were linked to either burning of sugarcane trash or leaching of sugarcane juices lost at harvest.

In contrast to the above mentioned studies, groundwater samples taken more recently (2011) in the lower Burdekin had much lower DOC concentrations, ranging from below the detection limit to a maxi-

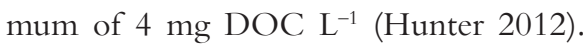
The reasons for the difference between these two studies are uncertain, but could be linked to either land management prac- tices and/or rainfall. Further investigation is warranted to clearly unravel the mechanism of DOC dynamics in deep drainage. Not only are the impacts on soil $\mathrm{C}$ balance important, but deep drainage of DOC into groundwater may also contribute to the reduction of groundwater pollution arising from leached nitrate- $\mathrm{N}\left(\mathrm{NO}_{3}-\mathrm{N}\right)$ through increased potential denitrification rates (Thayalakumaran et al. 2015).

\section{CONCLUSION AND FUTURE RESEARCH RECOMMENDATIONS}

The TOC losses in runoff in sugarcane systems ranged from 12 to $44 \mathrm{~kg} \mathrm{ha}^{-1}$ $\mathrm{y}^{-1}$ (11 to $\left.39 \mathrm{lb} \mathrm{ac}^{-1} \mathrm{yr}^{-1}\right)$. Carbon losses through terrestrial hydrological pathways can represent a significant impediment to achieving improved SOC sequestration in sugarcane farming systems of Australia. Future studies on SOC sequestration in sugarcane farming systems need to consider the $\mathrm{C}$ losses through runoff and deep drainage as a factor impacting the overall soil C balance.

\section{ACKNOWLEDGEMENTS}

This paper is a contribution from the Paddock to Reef Monitoring, Modelling, and Reporting Program. Funding for this research was contributed by the Queensland Department of Natural Resources and Mines, the Burnett Mary Regional Natural Resource Management Group and the Australian Government's Caring for our Country Program. Technical assistance from Stephen Ginns, Bill Rehbein, and Sheree Short is gratefully acknowledged. We acknowledge Ashley Webb of New South Wales Department of Primary Industries for the valuable feedback.

\section{REFERENCES}

ABARES (Australian Bureau of Agricultural and Resource Economics and Sciences Statistics). 2016. The Australian Bureau of Agricultural and
Resource Economics and Sciences Statisitics. http://www.abs.gov.au/.

Armour, J.D., P.N. Nelson, J.W. Daniells, V. Rasiah, and N.G. Inman-Bamber. 2013. Nitrogen leaching from the root zone of sugarcane and bananas in the humid tropics of Australia. Agriculture, Ecosystems and Environment 180:68-78.

ASMC (Australian Sugar Milling Council). 2016. Sugarcane Statistics. http://asmc.com.au/ industry-overview/statistics/.

Baker, J.M., T.E. Ochsner, R.T. Venterea, and T.J. Griffis. 2007. Tillage and soil carbon sequestration-What do we really know? Agriculture, Ecosystems and Environment 118:1-5.

Baskaran, S. 2002. A groundwater quality assessment of the Lower Pioneer Catchment, Qld [electronic resource]. In PANDORA electronic collection. Department of Agriculture, Fisheries, and Forestry, Canberra. http://nla.gov.au/nla.cat-vn3082658.

Baskaran, S., R.S. Brodie, K.L. Budd, and A.J. Plazinska. 2001. Assessment of groundwater quality and origin of saline groundwaters in the coastal aquifers of Bowen area, North Qld. In Bureau of Rural Sciences Canberra, eds. Baskaran, S., Australia Bureau of Rural Sciences, Department of Agriculture, Fisheries, and Forestry. http://nla. gov.au/nla.cat-vn2753311.

Bell, M.J., N.V. Halpin, D.N.Orange, and M.J. Haines. 2001. Effect of compaction and trash blanketing on rainfall infiltration in sugarcane soils. Proceedings of Australian Society of Sugarcane Technologists 23:161-167.

Bohl, H.P., G.D. Bonnett, D.J. Fanning, G.E. Rayment, and A.B. Davidson. 2002. Biological oxygen demand and sugars in irrigation water runoff from sugarcane fields, 24th Australian Society of Sugar Cane Technologists conference, 29 April 2 May, 2002, Cairns.

Canegrowers. 2016. Statistics, Facts, and Figures. http:// www.canegrowers.com.au/page/Industry_Centre/ About_Us/statistics-facts-figures/.

Carroll, C., D. Waters, S.Vardy, D.M. Silburn, S. Attard, P.J.Thorburn,A.M. Davis, N. Halpin, M. Schmidt, B.Wilson, and A. Clark. 2012. A Paddock to reef monitoring and modelling framework for the Great Barrier Reef: Paddock and catchment component. Marine Pollution Bulletin 65:136-149.

Chappell, A., J. Baldock, and J. Sanderman. 2015. The global significance of omitting soil erosion from soil organic carbon cycling schemes. Nature Climate Change 6:181-191.

Cole, J.J., Y.T. Prairie, N.F. Caraco, W.H. McDowell, L.J. Tranvik, R.G. Striegl, C.M. Duarte, P. Kortelainen, J.A. Downing, J.J. Middelburg, and J. Melack. 2007. Plumbing the global carbon cycle: 


\section{Figure 3}

Sugarcane farms in Australia: (a) cane burning, (b) harvested and burnt cane field, (c) sugarcane mechanical harvest, (d) trash mulch after harvest, (e) legume (soybean) rotation on trash mulch, and (f) compacted cane field without control traffic.

(a)

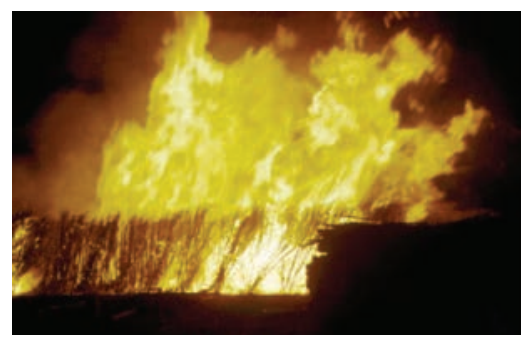

(d)

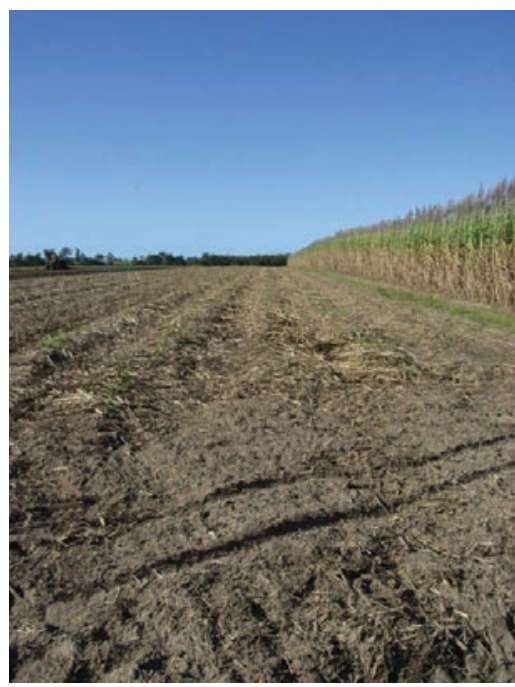

(b)

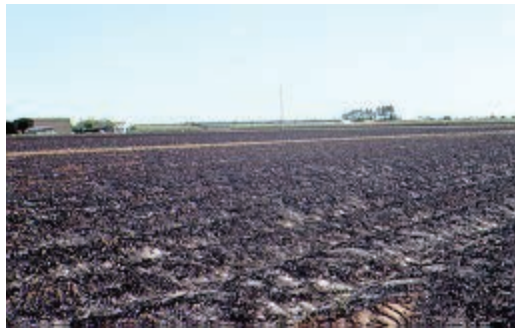

(e)

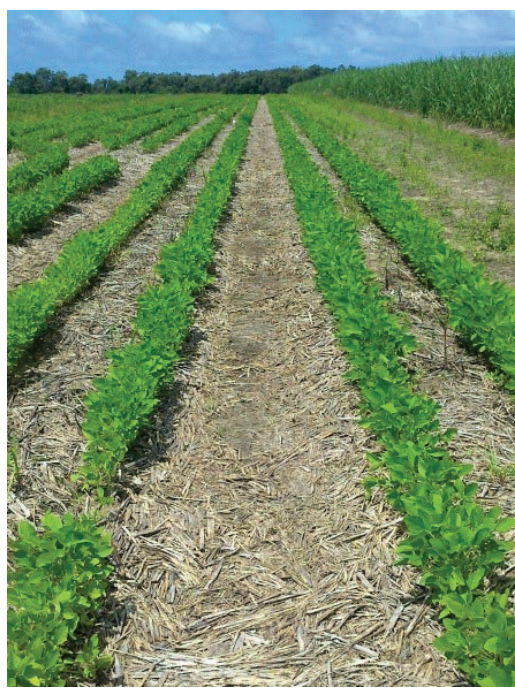

(c)

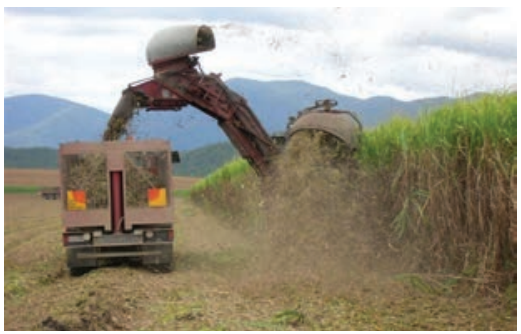

(f)

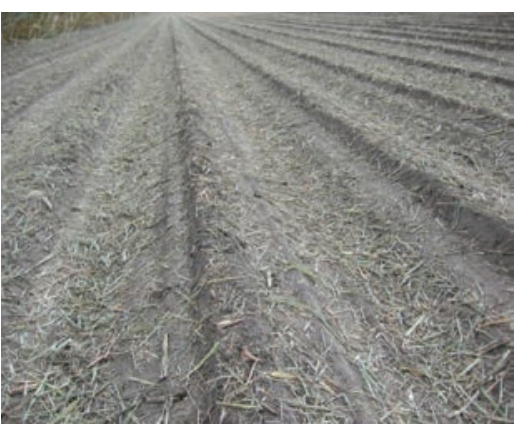

Integrating inland waters into the terrestrial carbon budget. Ecosystems 10:171-184.

Hulugalle, N.R., and F. Scott. 2008. A review of the changes in soil quality and profitability accomplished by sowing rotation crops after cotton in Australian Vertosols from 1970 to 2006. Soil Research 46:173-190.

Hunter, H.M. 2012. Nutrients and herbicides in ground water flows to the Great Barrier Reef lagoon: Processes, fluxes and links to onfarm management. http://trove.nla.gov.au/ version/195099695.

Lal, R. 2003. Soil erosion and the global carbon budget. Environment International 29:437-450.

Lal, R. 2005. Soil erosion and carbon dynamics. Soil and Tillage Research 81:137-142.

Locke, M.A., L.J. Krutz, R.W. Steinriede, and S. Testa. 2015. Conservation Management Improves Runoff Water Quality: Implications for Environmental Sustainability in a GlyphosateResistant Cotton Production System. Soil Science Society of America Journal 79:660-671.
Nachimuthu, G., N.V. Halpin, and M.J. Bell. 2016. Effect of sugarcane cropping systems on herbicide losses in surface runoff. Science of The Total Environment 557-558:773-784.

Page, K.L., M. Bell, and R.C. Dalal. 2013a. Changes in total soil organic carbon stocks and carbon fractions in sugarcane systems as affected by tillage and trash management in Queensland, Australia. Soil Research 51:608-614.

Page, K.L., R.C. Dalal, M.J. Pringle, M. Bell, Y.D. Dang, B. Radford, and K. Bailey. 2013b. Organic carbon stocks in cropping soils of Queensland, Australia, as affected by tillage management, climate, and soil characteristics. Soil Research 51:596-607.

Schulze, E.D., and A. Freibauer. 2005. Environmental science: Carbon unlocked from soils. Nature 437:205-206.

Six, J., H. Bossuyt, S. Degryze, and K. Denef. 2004. A history of research on the link between (micro) aggregates, soil biota, and soil organic matter dynamics. Soil and Tillage Research 79:7-31.
Six, J., E.T. Elliott, and K. Paustian. 2000. Soil macroaggregate turnover and microaggregate formation: a mechanism for $\mathrm{C}$ sequestration under no-tillage agriculture. Soil Biology and Biochemistry 32:2099-2103.

Stewart, L.K., P.B. Charlesworth, K.L. Bristow, and P.J. Thorburn. 2006. Estimating deep drainage and nitrate leaching from the root zone under sugarcane using APSIM-SWIM. Agricultural Water Management 81:315-334.

Smartcane BMP (Smartcane Best Management Practice). 2015. Smartcane best management practice (BMP). https://www.smartcane.com. au/home.aspx.

Thayalakumaran, T., K.L. Bristow, P.B. Charlesworth, and T. Fass. 2008. Geochemical conditions in groundwater systems: Implications for the attenuation of agricultural nitrate. Agricultural Water Management 95:103-115.

Thayalakumaran, T., M.J. Lenahan, and K.L. Bristow. 2015. Dissolved organic carbon in groundwater overlain by irrigated sugarcane. Groundwater 53:525-530 